\title{
Current Advances in Immunological Studies on the Vespidae Venom Antigen 5: Therapeutic and Prophylaxis to Hypersensitivity Responses
}

\author{
Murilo Luiz Bazon ${ }^{1}$, Lais Helena Silveira ${ }^{1}$, Patricia Ucelli Simioni ${ }^{2}$ (I) \\ and Márcia Regina Brochetto-Braga ${ }^{1,3, *(D)}$ \\ 1 Laboratório de Biologia Molecular de Artrópodes-LBMA-IB-RC-UNESP (Univ Estadual Paulista), Av. 24-A, \\ n_ 1515, Bela Vista, Rio Claro 13506-900, SP, Brazil; bazonmurilo@gmail.com (M.L.B.); \\ lenapascon@gmail.com (L.H.S.) \\ 2 Departamento de Biomedicina, Faculdade de Americana, FAM, Av. Joaquim Bôer, 733 Jardim Luciane, \\ Americana 13477-360, SP, Brazil; psimioni@gmail.com or patriciasimioni@fam.br \\ 3 Centro de Estudos de Venenos e Animais Peçonhentos-CEVAP (Univ Estadual Paulista), \\ Rua José Barbosa de Barros, 1780, Fazenda Experimental Lageado, Botucatu 18610-307, SP, Brazil \\ * Correspondence: mrbbraga@rc.unesp.br; Tel./Fax: +55-19-3526-4135
}

Received: 12 June 2018; Accepted: 5 July 2018; Published: 24 July 2018

\begin{abstract}
Although systemic reactions caused by allergenic proteins present in venoms affect a small part of the world population, Hymenoptera stings are among the main causes of immediate hypersensitivity responses, with risk of anaphylactic shock. In the attempt to obtain therapeutic treatments and prophylaxis to hypersensitivity responses, interest in the molecular characterization of these allergens has grown in the scientific community due to the promising results obtained in immunological and clinical studies. The present review provides an update on the knowledge regarding the immune response and the therapeutic potential of Antigen 5 derived from Hymenoptera venom. The results confirm that the identification and topology of epitopes, associated with molecular regions that interact with antibodies, are crucial to the improvement of hypersensitivity diagnostic methods.
\end{abstract}

Keywords: Antigen 5; Hymenoptera; immune response; hypersensitivity; anaphylaxis

Key Contribution: Antigen 5 has been frequently reported as the most allergenic venom component in almost all species of the genus belonging to family Vespidae. The high similarity among the Ag $5 \mathrm{~s}$ from different social wasp species has been used to explain the broad immune cross-reactivity among these proteins. Investigations of new variants of Ag 5 in other species of vespids are necessary for the development of more precise methodologies to aid in the accurate diagnosis of Vespidae venom allergies.

\section{Introduction}

The order Hymenoptera (Apocrita, Aculeata) is the main group among insects, which consists of three main families: Vespidae (comprising the best-known eusocial wasps from genera Polistes, Polybia, Vespa, Vespula and Dolichovesvula) [1-3], Formicidae (ants) and Apidae (bees). Social wasps are responsible for the increasing number of accidents recorded. In southeastern Brazil, Polybia paulista is one of the most relevant social wasp from the medical point of view, justifying the need for a more detailed characterization of the action mechanisms of the major proteins and allergenic compounds of its venom. Although the anaphylactic shock associated with immediate hypersensitivity reactions caused by allergenic proteins present in venoms affects a small part of the world population, 
Hymenoptera stings are among the main causes of systemic allergic responses [4,5], representing 9 to $23 \%$ of hypersensitivity reactions $[5,6]$.

The classical symptoms of stings are local burning, followed by edema and pain that can last for long periods. In addition, respiratory and circulatory reactions are common in allergic conditions $[4,5]$. The amount of venom to which the person has been exposed and the level of individual sensitivity to allergens should be taken into account while evaluating the immunological and clinical response [6-8]. The allergen components of the venom trigger the immune system response by producing specific antibodies [9]. In more severe stages, the immune response can lead to intense systemic inflammatory processes and fatal anaphylaxis reactions [4-6].

The molecular characterization of these allergens has brought promising results in clinical and immunological studies, supporting the development of therapeutic treatments and the prophylaxis of hypersensitivity responses. In addition, such knowledge can provide a better understanding of the allergic processes and allow the identification of epitopes and molecular regions interacting with antibodies $[6,8,10]$.

\section{Venom}

Eventual stings caused by Hymenoptera account for 20 to $40 \%$ of all types of anaphylaxis reported per year [11,12]. These venoms are composed of a complex mixture of proteins, enzymes, biologically active peptides and low molecular weight molecules, which are responsible for prolonged pain, edema, erythema, and allergic and systemic reactions [13,14]. Systemic reactions occur mainly in allergic patients, and clinical symptoms include generalized urticaria, angioedema, blood pressure drop, bronchospasm, cardiac arrest, and respiratory and anaphylactic shock [12,15-17].

Allergy diagnosis includes the history of a systemic reaction, a positive response to the skin test and the detection of venom-specific IgE antibodies. However, correct diagnosis is not always easy due to problems and limitations of both tests, especially when it is not possible to identify the species $[18,19]$. Moreover, allergic patients may present positive reactions to more than one insect venom of the Hymenoptera order, which may be caused by the cross reactivity of one or more allergens, considering the similarity between their primary sequences [12,15-17,20-24]. False-positive results can also be observed due to the cross-reactivity of patient IgE against the cross-reactive carbohydrate determinants (CCDs) present in most Hymenoptera venom allergens [23-27]. Having these difficulties solved and the correct diagnosis, immunotherapy with the whole venom of culprit insect represents the most effective treatment to reduce the risk of subsequent systemic reactions.

Wasp venom contains a variety of proteins such as phospholipases, hyaluronidases, Antigen 5, phosphatases, and serine proteases. Phospholipases have been chemically characterized in Apis melifera [28], venoms of neotropical wasps and ants [29-33], being responsible for the hydrolysis of the plasma membrane phospholipids, allowing the diffusion of some toxins into the cells. Phospholipase is also responsible for the formation of edema [34]. Hyaluronidase is a $45 \mathrm{kDa}$ glycoprotein [35] that hydrolyzes hyaluronic acid, a polysaccharide of high molecular mass located in the cellular interstice, with the property of maintaining cell adhesion. By the action of hyaluronidase, hyaluronic acid is transformed into small fragments, significantly reducing its viscosity and facilitating the diffusion of the venom components into the cells [36,37]. Phosphatases are found in large quantities in bee venom. These enzymes act as important allergens [38]. The venom of the wasp P. paulista, presents two types of phosphatase activity: acid and alkaline [32]. The esterases are important in the cell lysis process; however, its specific function has not been defined [38].

Social insect venoms do not contain significant amounts of proteases [39-41]. However, high protease activity has already been observed in venoms of the social wasp Polistes infuscatus, in Eciton burchelli ants and Bombus pennsylvanicus bees [38,42], and some protease activity was found in venoms of Hymenoptera: Vespidae, commonly found in São Paulo State [43]. Proteases catalyze the breakdown of peptide bonds into proteins, and the term "peptidases" may be used to denote any enzyme that hydrolyzes this type of linkage [44]. 


\section{Antigen 5}

King et al. (1978) identified a protein of approximately $23 \mathrm{kDa}$ of Dolichovespula maculata venom, naming it Antigen 5 (Ag 5) [45]. Since then, Antigen 5 has been frequently reported to be the most allergenic venom component in different species of social wasps, such as those belonging to the genus Dolichovespula, Vespa, Vespula, Polistes and Polybia [46-51]. Interestingly, Ag 5 also exhibits sequence homology with other proteins from various tissues, such as ant venoms, tomato leaf tobacco, mammalian testis proteins and human brain tumor [52].

This antigen belongs to a superfamily composed of proteins that are rich in cysteine residues (CRISP-Cysteine-Rich Secretory Proteins). Analysis of its domains have showed that it belongs to a CRISP subgroup, antigen 5 and Pr-1 (CAP) [52]. Ag 5-related proteins are also found in glial cell tumors [53]. According to Milne et al. (2003), Ag 5 is a protein that presents a high similarity of sequence with the protease of the venom of the family Conidae [54]. However, its biological function remains unknown and there is no knowledge of its biological action as a component of the venom of Vespidae family [47]. Animal studies have shown that, despite having no toxic action, Ag 5 may be associated with hypersensitivity responses [10].

\subsection{Superfamily CAP}

The superfamily CAP [cysteine-rich secretory proteins (CRISPs), Ag 5 and pathogenesis-1 (PR-1) related proteins] was named after the recognition of sequence similarity between CRISPs in eukaryotes, reptile venoms, plant pathogenic defense proteins or other stress responses (PR, PR-1) as found in tobacco leaf and tomato (P14-A-PRPs), CRISP and mammalian reproductive organ (TPX-1) specific proteins. CAP comprises three domains: $\mathrm{N}$-terminal $\mathrm{PR}$ domain, a hinge region and a cysteine-rich C-terminal domain [55]. Evidence suggests that CAPs plays an important role in the reproductive function, immune system, tumors and chronic diseases, organogenesis, and development of mammals. Asojo et al. (2005) reported a high similarity in the primary sequence and three-dimensional structure of the Na-ASP-2 protein (from CRISP-1 family and the one present in the nematode parasite Necator americanus) with Ag 5 of wasp venom. The potential of this protein to be used in the development of vaccines containing blocking or ligand antibodies to disrupt the cellular activation responses has already been demonstrated [52,56].

\subsection{Isoforms of $A g 5$}

Antigen 5 isolated and structurally characterized from the venom of the wasp Polybia scutellaris rioplatensis [49,57,58] has 207 amino acid residues, eight cysteine-rich residues forming four disulfide bonds, molecular mass around $23 \mathrm{kDa}$ and isoelectric point around nine [36,47,59]. The three-dimensional structure of venom Ag 5 of Vespula vulgaris was determined by X-ray crystallography, revealing that it has a secondary structure composed of five $\alpha$-helices and four $\beta$-sheets [59]. In proteomic studies, six isoforms of the Ag 5 of P. paulista have been identified [36]. The most abundant isoform has been extensively analyzed through mass spectrophotometry, and several of its post-translational modifications have been determined. Its structural model (Figure 1) showed three $\alpha$-helices, one helix $3_{10}$, and four $\beta$-sheets covering $28 \%$ and $17 \%, 9 \%$ of its sequence. Linear epitopes of this form have also been identified, mapped and immunologically characterized $[48,60]$.

Antigen 5 from the venoms of Polybia paulista (Poly p 5) and of P. scutellaris rioplatensis presented a high similarity (59.3-93.7\%) with its counterpart in the other Vespidae venom. Considering the diversity of substances in venoms and the scarce knowledge on the immunological potential of their allergenic components, such as the Ag 5 protein, further studies are needed to elucidate the processes involved in sensitization and allergic response [61]. The in-depth knowledge on the antigen-directed immune response presented in the venom of Hymenoptera may increase therapeutic possibilities for hypersensitive patients. 


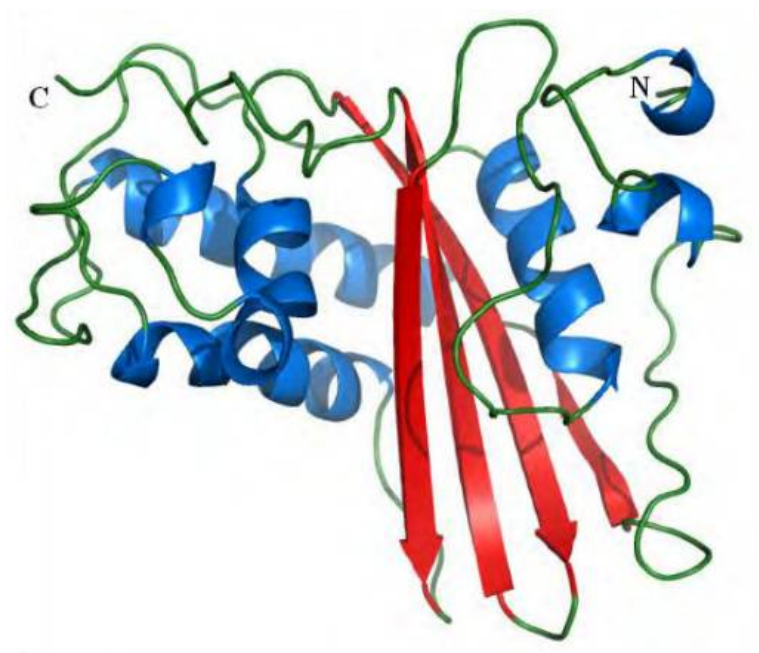

Figure 1. Three-dimensional molecular model of the antigen 5 allergen from social wasp Polybia paulista venom [60]. Reprinted with permission from [60], 2014, American Chemical Society.

\subsection{Immune Response to Allergens}

The immune responses to wasp venoms are complex and can include systemic allergic/hypersensitivity disorders [62]. In general, the wasp venom leads to a type I hypersensitivity reaction $[5,8,10]$. The antigens induce a helper (Th) $2 \mathrm{~T}$ lymphocyte cellular response profile, characterized by the production of specific IgE antibodies, as well as the secretion of interleukins (IL) -4 and IL-5 [63,64]. In the immune response, interferon gamma (IFN- $\gamma$ ), a proinflammatory cytokine, stimulates proinflammatory gene expression, such as the inducible synthase genes (iNOS) and cyclooxygenase-2 (COX-2). Macrophages, depending on the microenvironment, can differentiate into distinct types: classically activated macrophages (M1) and alternatively activated macrophages (M2) with anti-inflammatory profile [65,66]. The inducible isoform of nitric oxide synthase (iNOS) stimulates the production of nitric oxide (NO) from L-arginine [67], one of the functions of macrophages M1 [68]. Cytokines IL1, IL6, IL-12, and TNF- $\alpha$ are known to have inflammatory potential, whereas IL-10 and TGF- $\beta$ act in the modulation and inhibition of the immune response [69]. The gene encoding the iNOS enzyme is controlled by NF- $k B$, which plays a key role in inflammatory and immune cell responses [70]. The NF- $\mathrm{kB}$ transcription complex is present in the cytoplasm, bound to inhibitory proteins called I $\mathrm{B}$, maintaining them in the inactive form. Inhibition of NF- $\mathrm{KB}$ is associated with inflammatory diseases and can be a potential therapeutic target [71].

As noted above, exposure to this class of venom insect triggers a type I hypersensitivity reaction. IL-4 induces CD4 + T to differentiate into Th2, crucial for the entire development of the hypersensitivity framework. Immunotherapies for this type of response aim to increase suppressor cytokines, such as IL-10 and TNF- $\beta$ and decrease IL-4 secretion [72].

\subsection{Cross Reactivity}

One of the main obstacles to find an effective treatment for hypersensitivity responses is the occurrence of unspecific or undefined reactions, i.e., immune cross reactivity, a consequence of the significant similarity between the primary sequences of the allergenic proteins [50] and the presence of cross-reactive carbohydrate determinants (CCDs) of N-linked glycans [73-75] in some Hymenoptera venom allergens $[76,77]$.

Generally, the diagnostic of allergic response is based on the patient's clinical history, detection of specific IgE on the skin and/or blood of the allergic individual. When usual analyses are not conclusive, basophil activation or histamine releasing tests are performed to identify the culprit venom [26]. However, false-negative responses may occur due to the low amount of IgE detected or the low level of 
sensitivity of the test applied. False-positive responses can be caused by cross-reactivity with allergens from different venoms, whose epitopes have similar conformations [78,79].

The high similarity between the primary sequences of the allergens of several species of social wasps promotes a wide potential for the occurrence of cross reactivity between the different species. The similarity between Ag 5 from different social wasp species could explain the broad cross-reactivity between proteins. Posttranslational modifications (PTMS) of different species, such as glycosylation, could also be a cause of cross-reactivity of the Hymenoptera venom $[47,60]$. The Ag 5 allergen demonstrated cross reactivity with the venom of other species as Agelaia pallipes and Apis mellifera, being immunoreactive in the experiments performed $[51,80,81]$. The presence of $\operatorname{IgE}$ against carbohydrate-determining regions (CCD) occurred in more than $80 \%$ of the samples positively tested for both species [82].

Studies on the primary structure and immunological response of the Ag 5 from venom from wasp species (endemic in the northern hemisphere) have reported that the identity of Ag 5 sequences in species of the same genus is approximately $98 \%$, whereas among the different genera, such as Vespula and Polistes, this value is approximately $57 \%$ (Figure 2) [55]. According to the allergen list from the International Union of Immunological Societies (IUIS), Ag 5 is present in venoms of almost all species of the genus belonging to family Vespidae, including Solenopsis ants (Solenopsis invicta, Sol i 3; Solenopsis richteri, Sol r 3; Solenopsis saevissima, Sol s 3), whose allergens have high similarity to Ag 5 from other Vespidae venoms [83].
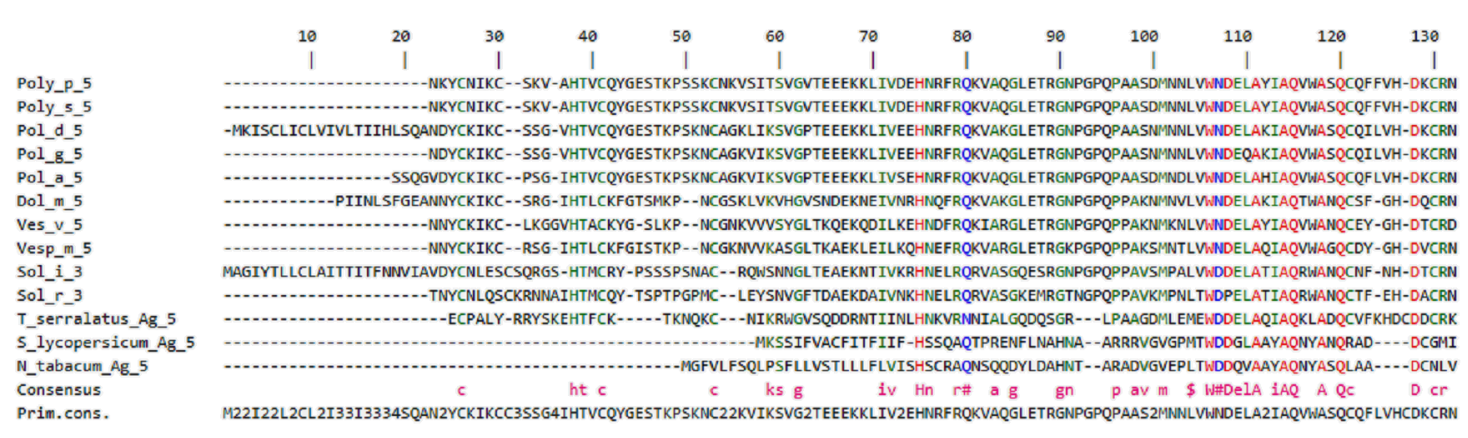

Poly_P_5
Poly_555
Pol_d_5
Pol_g_5
Pol_a_5
Dol_m_5
Ves_v_5
Vesp_m_5
Sol_i_3
Sol_r_3
T_serralatus_Ag_5
S_lycopersicum_Ag_5
N_tabacum_Ag_5
Consensus
Prim.cons.

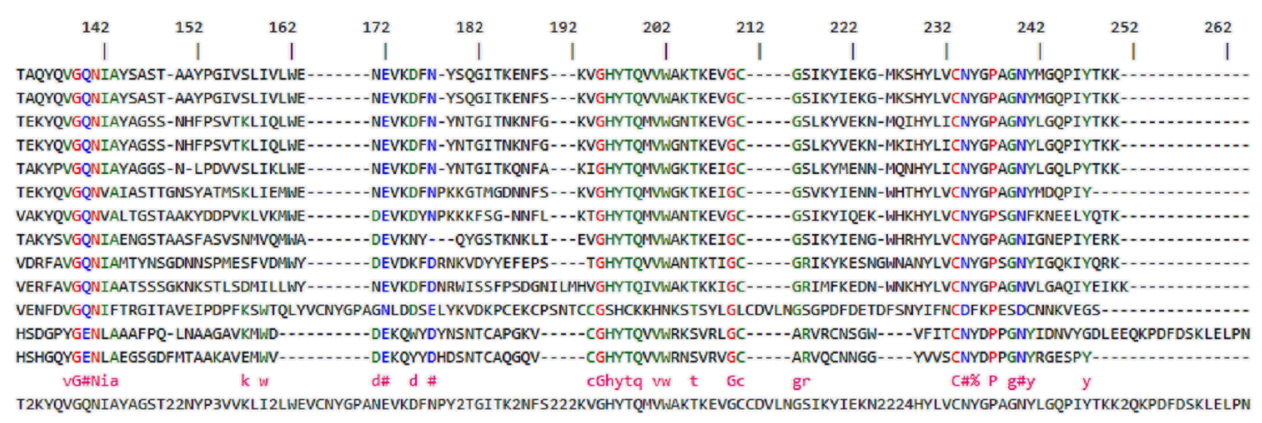

Figure 2. Multiple alignment of primary sequences of venom allergen $\mathrm{Ag} 5$ of wasps (Polybia, Polistes, Dolichovespula, Vespula and Vespa) with sequences from other members of the superfamily CAP (Solenopsis invicta, Solenopsis richteri, Tityus serrulatus, Solanum lycopersicum and Nicotiana tabacum). Data referenced in GenBank and adapted.

Nevertheless, the IgE associated with the cross-activity between Ag 5 of V. vulgaris and Sol i 3 from Solenopsis invicta, which show $44 \%$ similarity on amino acid sequence [55], has not been investigated. The fact that the Ag 5 homologous proteins found in some ant venoms do not exhibit cross-reactive antigen reactivity with the same protein in vespid venoms is a consistent result regarding the low degree of structure conservation and the length of the loops in these allergens. However, some cross reactivity has been observed between Ag 5 of vespids and the homologous proteins (from CRISP family) of other animals [53]. Müller et al. [84] observed cross reactivity in human serum between 
V. vulgaris Ag 5 venom allergen and mammalian testis proteins belonging to the family of cysteine-rich secretory proteins (hCRIsp).

Van Vaerenbergh et al. [18] demonstrated the expression of a molecule similar to wasp venom Ag 5 of Apis mellifera bee venom and named apidaecina. In addition, the authors reported that this molecule is expressed in different tissue types, such as the hypopharyngeal, brain, and midgut glands, more abundantly in the brain. The comparative analysis of this sequence was clearly paralleled to the sequences of Ag 5 already described for wasp (Vespula, Vespa, Dolichovespula, Polistes, Polybia and Rhynchium) and ant (Pachycondyla and Solenopsis) venoms [18,83].

Comparing the primary sequences of Dol $\mathrm{m} 5$ with those of the defense proteins related to the pathogenicity of these viruses in plants, $28 \%$ of conservation was found. When consuming tomato products or smoking, these patients developed antibodies against PRPs, which in turn showed cross reactivity with Dol $\mathrm{m} 5$ of Dolichovespula maculate $[59,85]$.

Despite this high similarity between the Ag 5 proteins of the P. paulista and P. scutellaris venoms, the component was described as a hypoallergenic molecule in P. scutellaris [44,65]. This result is conflicting with studies on P. paulista $[34,35]$ and other wasps, such as Vespula vulgaris (Ves v 5) [58,86-88]. Antigen 5 from P. scutellaris was reported as a variant with reduced reactivity to specific IgE and anaphylactic activity and so, it was considered an important allergen to be used in immunotherapy of allergic patients [49]. Thus, the importance of cross-reactivity among insect venoms in clinical practice is unquestionable, since these interactions have a direct impact on the diagnosis and on the definition of the best therapeutic approach. Using recombinant Ag 5, immunologically and structurally fully characterized, from seven allergy-relevant species from Vespoidea group, Schiener et al. [16,20] investigated the immunological IgE cross-reactivity through ImmunoCAP, ELISA, cross-inhibition and basophil activation test (BAT). They concluded that Ag 5 is not an appropriate diagnostic marker for vespid venom, since high levels of cross-reactivity were observed in many of the analyses performed. Therefore, the investigation of new Ag 5 variants in other vespid species and the development of more accurate methodologies may assist the precise diagnostic of wasp venom allergies.

\subsection{Potential of the Molecule Ag 5 in Immunotherapy}

Considering the evolutionary diversity of proteins from CAP superfamily, several functional relations have been proposed for them, such as the regulation of the immune system [52]. Ag 5 is part of the salivary proteins that supposedly function in the suppression of the host immune system or in the prevention of coagulation [89-91]. Ag 5 has been demonstrated to trigger immune and inflammatory responses via mast cell activation. This activation occurs when molecules associate with G-protein receptors through different mechanisms: (a) when polycationic peptides bind to the G-protein receptors present in cell membranes and $\beta \gamma$ subunits stimulate phospholipase $C$, leading to the release of mediators [92] or (b) by the cross-linking of IgE receptors on the cell membrane. This results in the aggregation of high affinity receptors FceRI and the secretion of substances that may have effector, immunoregulatory or autocrine actions.

Mast cell activation generates three types of biological responses: secretion of preformed granule contents through a regulated process of exocytosis, synthesis and secretion of lipid mediators, and synthesis and secretion of cytokines. These responses occur due to FcERI cross-linking, which initiates a signaling cascade in the mast cells, involving protein tyrosine kinases and leading to the release of mediators $[93,94]$.

The evidence of the biological function of the $\mathrm{Ag} 5$ is related to the poor inhibition of trypsin in human glioblastoma cells [95]. Trypsin inhibition has not been reported for other species of wasps and bees. Venom $\mathrm{Ag} 5$ from several wasp species has been expressed as recombinant proteins in both prokaryotic and eukaryotic systems [87]. Thus, expression of the Ag 5 allergen has the potential to provide a large number molecule for diagnosis and therapy. In general, recombinant allergens have been considered a promising alternative for the improvement of specific allergen immunotherapy and in in vitro diagnosis of allergic sensitization [96]. 
Bohle et al. [97] provided evidences that the T-cell immune response to Hymenoptera allergens differs from the typical Th2-dominated response observed to the most inhalant allergens. Their report showed that the immune response to Ag 5 involves high secretion of IL-4 and low levels of IFN-gamma. Surprisingly, the secretion of IL-10, which commonly is associated with the suppression of allergen-specific $\mathrm{T}$ cell responses in healthy individuals, had no differences between Ves $\mathrm{v} 5$-specific $\mathrm{T}$ cell clones from allergic and non-allergic individuals [97].

Antigens 5 is an inappropriate marker for differential $\operatorname{IgE}$ diagnostics in vespid venom allergy since it can cause extensive cross-reactivity in various diagnostic settings [20]. However, there are few reports related with immunotherapies with Ag 5 in use $[15,16,58]$. Although the European guidelines still recommend the venom immunotherapy with Vespula venom in order to achieve an adequate protection against Vespa crabro venom, studies with Antigen 5 showed that sensitization may occur. Immunotherapy, when available, is still the safest method, since venom extracts are available [98].

\section{Future Perspectives}

$\mathrm{Ag} 5$ is a common allergen found in social wasp venoms and in many different animal and plant systems. Immunotherapy with venom extracts from social insects is highly effective and widely used in the treatment of patients with a history of anaphylaxis [87]. Specific immunotherapy is the only treatment for type I allergies and is based on the accurate allergy history of the individual and the results of skin and RAST (Radioallergosorbent) diagnoses, which confirm the presence of IgE $[99,100]$. The risk of inefficiency of specific immunotherapy can be associated with de novo sensitization to new allergenic proteins (or cross-reacting allergens) to which patient had not presented any reaction [19]. On the other hand, patients presenting systemic reactions and opposed immunotherapy, lost sensitivity in the same proportion as those who underwent treatment [101]. One way to reduce the risk of anaphylaxis during specific immunotherapy is to use modified allergens, with decreased interaction [102]. Another possibility is the preparation of genetically modified allergens or peptide allergenic derivatives with reduced allergenic activity that will induce a specific interaction of the allergen based on IgG antibodies [103]. Although antigen 5 function has not been clarified, the molecule is a strong candidate to be used in immunotherapy in patients allergic to social wasp venom. It has been demonstrated that the soluble recombinant form of Poly $\mathrm{p} 5$ (rPoly p 5) obtained through expression in $P$. pastoris is allergenic and induces an immune response that occurs qualitatively at the same level as its natural variant (nPoly p 5) [104]. This finding strongly indicates that this molecule can be effectively used for the molecular diagnosis of allergies. Studies on the pro-or anti-inflammatory potential of Ag 5, specifically on its ability to stimulate nitric oxide production or cytokine secretion, may be of great relevance for the comprehension of the immunomodulatory potential of this protein.

Author Contributions: M.L.B. and M.R.B.-B. designed the review. M.L.B., P.U.S., M.R.B.-B. and L.H.S. wrote the first version of the review and performed the bibliography searches. M.L.B., M.R.B.-B. and P.U.S. revised all versions of the manuscript, contributed through discussions and provided the answers to reviewer's and editor's comments. M.L.B. improved the quality of Figures and submitted it.

Funding: This research was funded by São Paulo Research Foundation (FAPESP). Grants \#2014/13936-7, \#2017/18422-0.

Acknowledgments: We acknowledge the financial support from São Paulo Research Foundation (FAPESP) (Grants \#2014/13936-7 and \#2017/18422-0 to Márcia Regina Brochetto Braga). The authors also thank Postgraduate Program of Biological Sciences (Cellular and Molecular Biology) at State University of São Paulo (UNESP)-Rio Claro-SP-Brazil, CNPq (National Council of Scientific Researches) and FAPESP (Proc. no. 2017/07988-2) for providing Master and Doctoral scholarship respectively to Murilo Luiz Bazon and also to CAPES-DS (Coordenação de Aperfeiçoamento de Pessoal de Nível Superior) for Master scholarship to Lais Helena Silveira.

Conflicts of Interest: The authors declare no conflict of interest. 


\section{References}

1. Jeanne, R.L. Evolution of Social Behavior in the Vespidae. Annu. Rev. Entomol. 1980, 25, 371-396. [CrossRef]

2. Pickett, K.; Wenzel, J. Phylogenetic analysis of the New World Polistes (Hymenoptera: Vespidae: Polistinae) using morphology and molecules. J. Kansas Entomol. Soc. 2004, 77, 742-760. [CrossRef]

3. Johnson, B.R.; Borowiec, M.L.; Chiu, J.C.; Lee, E.K.; Atallah, J.; Ward, P.S. Phylogenomics resolves evolutionary relationships among ants, bees, and wasps. Curr. Biol. 2013, 23, 2058-2062. [CrossRef] [PubMed]

4. Wolverton, W.; Beakes, D.E.; Huebner, S. Hymenoptera Venom Hypersensitivity Evaluation. J. Allergy Clin. Immunol. 2013, 131, AB26. [CrossRef]

5. Casale, T.B.; Burks, A.W.; Solomon, C.G.; Casale, T.B.; Burks, A.W. Hymenoptera-Sting Hypersensitivity. N. Engl. J. Med. 2014, 370, 1432-1439. [CrossRef] [PubMed]

6. Hamilton, R.G. Diagnostic methods for insect sting allergy. Curr. Opin. Allergy Clin. Immunol. 2004, 4, $297-306$. [CrossRef] [PubMed]

7. Elieh Ali Komi, D.; Shafaghat, F; Zwiener, R.D. Immunology of Bee Venom. Clin. Rev. Allergy Immunol. 2018, 54, 386-396. [CrossRef] [PubMed]

8. Golden, D.B.K.K. New directions in diagnostic evaluation of insect allergy. Curr. Opin. Allergy Clin. Immunol. 2014, 14, 334-339. [CrossRef] [PubMed]

9. Bordon, K.C.F.F.; Wiezel, G.A.; Amorim, F.G.; Arantes, E.C. Arthropod venom Hyaluronidases: Biochemical properties and potential applications in medicine and biotechnology. J. Venom. Anim. Toxins Incl. Trop. Dis. 2015, 21, 43. [CrossRef] [PubMed]

10. Demain, J.G.; Minaei, A.A.; Tracy, J.M. Anaphylaxis and insect allergy. Curr. Opin. Allergy Clin. Immunol. 2010, 10, 318-322. [CrossRef] [PubMed]

11. Bilò, B.M.; Bonifazi, F. Epidemiology of insect-venom anaphylaxis. Curr. Opin. Allergy Clin. Immunol. 2008, 8, 330-337. [CrossRef] [PubMed]

12. Worm, M.; Moneret-Vautrin, A.; Scherer, K.; Lang, R.; Fernandez-Rivas, M.; Cardona, V.; Jutel, M.; Poziomkowska-Gesicka, I.; Papadopoulos, N.G.; Beyer, K.; et al. First European data from the network of severe allergic reactions (NORA). Allergy 2014, 69, 397-404. [CrossRef] [PubMed]

13. Srisong, H.; Daduang, S.; Lopata, A.L. Current advances in ant venom proteins causing hypersensitivity reactions in the Asia-Pacific region. Mol. Immunol. 2016, 69, 24-32. [CrossRef] [PubMed]

14. Perez-Riverol, A.; Justo-Jacomini, D.L.; de Lima Zollner, R.; Brochetto-Braga, M.R. Facing hymenoptera venom allergy: From natural to recombinant allergens. Toxins (Basel) 2015, 7, 2551-2570. [CrossRef] [PubMed]

15. Fiedler, C.; Miehe, U.; Treudler, R.; Kiess, W.; Prenzel, F. Long-term follow-up of children after venom immunotherapy: Low adherence to anaphylaxis guidelines. Int. Arch. Allergy Immunol. 2017, 172, 167-172. [CrossRef] [PubMed]

16. Schiener, M.; Graessel, A.; Ollert, M.; Schmidt-Weber, C.B.; Blank, S. Allergen-specific immunotherapy of Hymenoptera venom allergy-Also a matter of diagnosis. Hum. Vaccines Immunother. 2017, 13, 2467-2481. [CrossRef] [PubMed]

17. Visitsunthorn, N.; Kijmassuwan, T.; Visitsunthorn, K.; Pacharn, P.; Jirapongsananuruk, O. Clinical characteristics of allergy to Hymenoptera stings. Pediatric Emergency Care 2017. [CrossRef] [PubMed]

18. Van Vaerenbergh, M.; De Smet, L.; Rafei-Shamsabadi, D.; Blank, S.; Spillner, E.; Ebo, D.G.; Devreese, B.; Jakob, T; de Graaf, D.C. IgE recognition of chimeric isoforms of the honeybee (Apis mellifera) venom allergen Api m 10 evaluated by protein array technology. Mol. Immunol. 2015, 63, 449-455. [CrossRef] [PubMed]

19. Ollert, M.; Blank, S. Anaphylaxis to insect venom allergens: Role of molecular diagnostics. Curr. Allergy Asthma Rep. 2015, 15, 26. [CrossRef] [PubMed]

20. Schiener, M.; Eberlein, B.; Moreno-Aguilar, C.; Pietsch, G.; Serrano, P.; McIntyre, M.; Schwarze, L.; Russkamp, D.; Biedermann, T.; Spillner, E. ; et.al. Application of recombinant antigen 5 allergens from seven allergy-relevant Hymenoptera species in diagnostics. Allergy 2017, 72, 98-108. [CrossRef] [PubMed]

21. Hemmer, W. Kreuzreaktionen zwischen den Giften von Hymenopteren unterschiedlicher Familien, Gattungen und Arten. Der Hautarzt 2014, 65, 775-779. [CrossRef] [PubMed]

22. Incorvaia, C.; Mauro, M.; Pravettoni, V.; Pucci, S. Hypersensitivity to Hymenoptera venom: Advances in diagnosis and implications for treatment. Recent Pat. Inflamm. Allergy Drug Discov. 2011, 5, 128-135. [CrossRef] [PubMed] 
23. Jakob, T.; Rafei-Shamsabadi, D.; Spillner, E.; Müller, S. Diagnostics in Hymenoptera venom allergy: Current concepts and developments with special focus on molecular allergy diagnostics. Allergo J. Int. 2017, 26, 93-105. [CrossRef] [PubMed]

24. Jakob, T.; Müller, U.; Helbling, A.; Spillner, E. Component resolved diagnostics for hymenoptera venom allergy. Curr. Opin. Allergy Clin. Immunol. 2017, 17, 363-372. [CrossRef] [PubMed]

25. Hemmer, W.; Focke, M.; Kolarich, D.; Dalik, I.; Götz, M.; Jarisch, R. Identification by immunoblot of venom glycoproteins displaying immunoglobulin E-binding N-glycans as cross-reactive allergens in honeybee and yellow jacket venom. Clin. Exp. Allergy 2004, 34, 460-469. [CrossRef] [PubMed]

26. Spillner, E.; Blank, S.; Jakob, T. Hymenoptera allergens: From venom to venome. Front. Immunol. $2014,5,77$. [CrossRef] [PubMed]

27. Altmann, F. Coping with cross-reactive carbohydrate determinants in allergy diagnosis. Allergo J. Int. 2016, 25, 98-105. [CrossRef] [PubMed]

28. Habermann, E.; Neumann, W.P. Purification of phospholipase A of bee venom. Biochem. Z. 1957, 328, 465-473. [PubMed]

29. Hoffman, D.R.; Sakell, R.H.; Schmidt, M. Sol i 1, the phospholipase allergen of imported fire ant venom. J. Allergy Clin. Immunol. 2005, 115, 611-616. [CrossRef] [PubMed]

30. Wiese, M.D.; Brown, S.G.; Chataway, T.K.; Davies, N.W.; Milne, R.W.; Aulfrey, S.J.; Heddle, R.J. Myrmecia pilosula (Jack Jumper) ant venom: Identification of allergens and revised nomenclature. Allergy Eur. J. Allergy Clin. Immunol. 2007, 62, 437-443. [CrossRef] [PubMed]

31. Castro, F.F.M.; Palma, M.S.; Brochetto-Braga, M.R.; Malaspina, O.; Lazaretti, J.; Baldo, M.A. Biochemical properties and study of antigenic cross-reactivity between Africanized honey bee and wasp venom. J. Investig. Allergol. Clin. Immunol. 1994, 4, 37-41. [PubMed]

32. De Oliveira, M.R.; Palma, M.S. Polybitoxins: A group of phospholipases $A_{2}$ from the venom of the neotropical social wasp paulistinha (Polybia paulista). Toxicon 1998, 36, 189-199. [CrossRef]

33. Costa, H.; Palma, M.S. Agelotoxin: A phospholipase $\mathrm{A}_{2}$ from the venom of the neotropical social wasp cassununga (Agelaia pallipes pallipes) (Hymenoptera-Vespidae). Toxicon 2000, 38, 1367-1379. [CrossRef]

34. Santos, L.D.; Santos, K.S.; de Souza, B.M.; Arcuri, H.A.; Cunha-Neto, E.; Castro, F.M.; Kalil, J.E.; Palma, M.S. Purification, sequencing and structural characterization of the phospholipase A1 from the venom of the social wasp Polybia paulista (Hymenoptera, Vespidae). Toxicon 2007, 50, 923-937. [CrossRef] [PubMed]

35. Kolarich, D.; Léonard, R.; Hemmer, W.; Altmann, F. The N-glycans of yellow jacket venom hyaluronidases and the protein sequence of its major isoform in Vespula vulgaris. FEBS J. 2005, 272, 5182-5190. [CrossRef] [PubMed]

36. Dos Santos, L.D.; Santos, K.S.; Pinto, J.R.A.; Dias, N.B.; Souza, B.M.; dos Santos, M.F.; Perales, J.; Domont, G.B.; Castro, F.M.; Kalil, J.E.; et al. Profiling the proteome of the venom from the social wasp Polybia paulista: A clue to understand the envenoming mechanism. J. Proteome Res. 2010, 9, 3867-3877. [CrossRef] [PubMed]

37. Riches, H.R.C. Hypersensitivity to bee venom. Bee World 1982, 63, 7-22. [CrossRef]

38. Schmidt, J.O.; Yamane, S.; Matsuura, M.; Starr, C.K. Hornet venoms: Lethalities and lethal capacities. Toxicon 1986, 24, 950-954. [CrossRef]

39. Schmidt, J.H. Biochemistry of insect venoms. Annu. Rev. Entomol. 1982, 27, 339-368. [CrossRef] [PubMed]

40. Dotimas, E.M.; Hamid, K.R.; Hider, R.C.; Ragnarsson, U. Isolation and structure analysis of bee venom mast cell degranulating peptide. Biochim. Biophys. Acta (BBA)/Protein Struct. Mol. 1987, 3, 285-293. [CrossRef]

41. Banks, B.E.C.; Shipolini, R.A. Chemistry and Pharmacology of Honey-Bee Venom. In Venoms of the Hymenoptera: Biochemical, Pharmacological and Behaviour Aspects; Piek, T., Ed.; Academic Press Inc.: Cambridge, MA, USA, 1986. Available online: https://books.google.com.br/books?hl=pt-BR\&lr=\&id= xBQIBQAAQBAJ\&oi=fnd\&pg=PA329\&dq=Chemistry+and+pharmacology+of+honey-bee+venom.+In: +Venoms+of+the+Hymenoptera\&ots=CC3St9vfZ0\&sig=2E2gP77xzN0Cfwy4XhwVCksfiig (accessed on 16 May 2018).

42. Hoffman, D.R.; Jacobson, R.S. Allergens in hymenoptera venom XXVII: Bumblebee venom allergy and allergens. J. Allergy Clin. Immunol. 1996, 97, 812-821. [CrossRef]

43. Da Silva, G.P.; Brochetto-Braga, M.R.; Ruberti, M.; Ternero, M.L.L.; Gobbi, N.; Silva, G.P. A comparative study of protein and enzymatic activity in venoms of some common wasps (Hymenoptera: Vespidae) from São Paulo State. Sociobiology 2004, 44, 271-282. 
44. Rawlings, N.D. Protease families, evolution and mechanism of action. In Proteases Structure and Function; Springer: Vienna, Austria, 2013; pp. 1-36.

45. King, T.P.; Sobotka, A.K.; Alagon, A.; Kochoumian, L.; Lichtenstein, L.M. Protein allergens of white-faced hornet, yellow hornet, and yellow jacket venoms. Biochemistry 1978, 17, 5165-5174. [CrossRef] [PubMed]

46. Hoffman, D.R. Allergens in hymenoptera venom XV: The immunologic basis of vespid venom cross-reactivity. J. Allergy Clin. Immunol. 1985, 75, 611-613. [CrossRef]

47. Aparecido Dos Santos-Pinto, J.R.; Delazari Dos Santos, L.; Arcuri, H.A.; Ribeiro Da Silva Menegasso, A.; Pêgo, P.N.; Santos, K.S.; Castro, F.M.; Kalil, J.E.; De-Simone, S.G.; Palma, M.S. B-cell linear epitopes mapping of antigen-5 allergen from Polybia paulista wasp venom. J. Allergy Clin. Immunol. 2015, 135, $264-267$. [CrossRef] [PubMed]

48. Nakajima, T.; Yasuhara, T.; Uzu, S.; Wakamatsu, K.; Miyazawa, T.; Fukuda, K.; Tsukamoto, Y. Wasp venom peptides; wasp kinins, new cytotrophic peptide families and their physico-chemical properties. Peptides 1985, 6, 425-430. [CrossRef]

49. Pirpignani, M.L.; Rivera, E.; Hellman, U.; Biscoglio de Jiménez Bonino, M. Structural and immunological aspects of Polybia scutellaris Antigen 5. Arch. Biochem. Biophys. 2002, 407, 224-230. [CrossRef]

50. Pantera, B.; Hoffman, D.R.; Carresi, L.; Cappugi, G.; Turillazzi, S.; Manao, G.; Severino, M.; Spadolini, I.; Orsomando, G.; Moneti, G. ; et. al. Characterization of the major allergens purified from the venom of the paper wasp Polistes gallicus. Biochim. Biophys. Acta Gen. Subj. 2003, 1623, 72-81. [CrossRef]

51. An, S.; Chen, L.; Wei, J.-F.; Yang, X.; Ma, D.; Xu, X.; Xu, X.; He, S.; Lu, J.; Lai, R. Purification and characterization of two new allergens from the venom of Vespa magnifica. PLoS ONE 2012, 7, e31920. [CrossRef] [PubMed]

52. Gibbs, G.M.; Roelants, K.; O’Bryan, M.K. The CAP superfamily: Cysteine-rich secretory proteins, antigen 5, and pathogenesis-related 1 proteins-Roles in reproduction, cancer, and immune defense. Endocr. Rev. 2008, 29, 865-897. [CrossRef] [PubMed]

53. Hoffman, D.R. Hymenoptera venom allergens. Clin. Rev. Allergy Immunol. 2006, 30, 109-128. [CrossRef]

54. Milne, T.J.; Abbenante, G.; Tyndall, J.D.A.; Halliday, J.; Lewis, R.J. Isolation and characterization of a cone snail protease with homology to CRISP proteins of the pathogenesis-related protein superfamily. J. Biol. Chem. 2003, 278, 31105-31110. [CrossRef] [PubMed]

55. Padavattan, S.; Schmidt, M.; Hoffman, D.R.; Marković-Housley, Z. Crystal Structure of the Major Allergen from Fire Ant Venom, Sol i 3. J. Mol. Biol. 2008, 383, 178-185. [CrossRef] [PubMed]

56. Asojo, O.A.; Goud, G.; Dhar, K.; Loukas, A.; Zhan, B.; Deumic, V.; Liu, S.; Borgstahl, G.E.O.; Hotez, P.J. $\mathrm{X}$-ray structure of Na-ASP-2, a pathogenesis-related-1 protein from the nematode parasite, Necator americanus, and a vaccine antigen for human hookworm infection. J. Mol. Biol. 2005, 346, 801-814. [CrossRef] [PubMed]

57. Cascone, O.; Amaral, V.; Ferrara, P.; Vita, N.; Guillemot, J.C.; Díaz, L.E. Purification and characterization of two forms of antigen 5 from Polybia scutellaris venom. Toxicon 1995, 33, 659-665. [CrossRef]

58. Vinzón, S.E.; Marino-Buslje, C.; Rivera, E.; Biscoglio de Jiménez Bonino, M. A naturally occurring hypoallergenic variant of vespid antigen 5 from Polybia scutellaris venom as a candidate for allergen-specific immunotherapy. PLoS ONE 2012, 7, e41351. [CrossRef] [PubMed]

59. Henriksen, A.; King, T.P.; Mirza, O.; Monsalve, R.I.; Meno, K.; Ipsen, H.; Larsen, J.N.; Gajhede, M.; Spangfort, M.D. Major venom allergen of yellow jackets, ves v 5: Structural characterization of a pathogenesis-related protein superfamily. Proteins Struct. Funct. Genet. 2001, 45, 438-448. [CrossRef] [PubMed]

60. Dos Santos-Pinto, J.R.A.; dos Santos, L.D.; Andrade Arcuri, H.; Castro, F.M.; Kalil, J.E.; Palma, M.S. Using Proteomic Strategies for Sequencing and Post-Translational Modifications Assignment of Antigen-5, a Major Allergen from the Venom of the Social Wasp Polybia paulista. J. Proteome Res. 2014, 13, 855-865. [CrossRef] [PubMed]

61. Goldberg, A.; Shefler, I.; Panasoff, J.; Paitan, Y.; Confino-Cohen, R. Immunotherapy with commercial venoms is efficacious for anaphylactic reactions to vespa orientalis stings. Int. Arch. Allergy Immunol. 2013, 161, 174-180. [CrossRef] [PubMed]

62. Tanno, L.K.; Calderon, M.; Papadopoulos, N.G.; Demoly, P. Mapping hypersensitivity/allergic diseases in the International Classification of Diseases (ICD)-11: Cross-linking terms and unmet needs. Clin. Transl. Allergy 2015, 5, 20. [CrossRef] [PubMed] 
63. Justo Jacomini, D.L.; Gomes Moreira, S.M.; Campos Pereira, F.D.; Zollner, R.D.L.; Braga, M.R.B. Reactivity of IgE to the allergen hyaluronidase from Polybia paulista (Hymenoptera, Vespidae) venom. Toxicon 2014, 82, 104-111. [CrossRef] [PubMed]

64. Thomas, W.R. Broad perspectives of allergen specific immunotherapy. Hum. Vaccines Immunother. 2017, 13, 2385-2389. [CrossRef] [PubMed]

65. Liu, C.; Li, Y.; Yu, J.; Feng, L.; Hou, S.; Liu, Y. Targeting the shift from M1 to M2 macrophages in experimental autoimmune encephalomyelitis mice treated with fasudil. PLoS ONE 2013, 8, e54841. [CrossRef] [PubMed]

66. Robbe, P.; Draijer, C.; Borg, T.R.; Luinge, M.; Timens, W.; Wouters, I.M.; Melgert, B.N.; Hylkema, M.N. Distinct macrophage phenotypes in allergic and nonallergic lung inflammation. Am. J. Physiol. Lung Cell. Mol. Physiol. 2015, 308, L358-L367. [CrossRef] [PubMed]

67. Davis, M.J.; Tsang, T.M.; Qiu, Y.; Dayrit, J.K.; Freij, J.B.; Huffnagle, G.B.; Olszewski, M.A. Macrophage M1/M2 polarization dynamically adapts to changes in cytokine microenvironments in Cryptococcus neoformans infection. mBio 2013, 4, e00264-13. [CrossRef] [PubMed]

68. MacMicking, J.; Xie, Q.W.; Nathan, C. Nitric oxide and macrophage function. Annu. Rev. Immunol. 1997, 15, 323-350. [CrossRef] [PubMed]

69. Mota, I.; Martins, C.; Borrego, L.M. Regulatory B cells and allergy: Uncovering the link. J. Investig. Allergol. Clin. Immunol. 2017, 27, 204-212. [CrossRef] [PubMed]

70. Pahl, H.L. Activators and target genes of Rel/NF-kappaB transcription factors. Oncogene 1999, 18, 6853-6866. [CrossRef] [PubMed]

71. Zingarelli, B.; Hake, P.W.; O'Connor, M.; Denenberg, A.; Kong, S.; Aronow, B.J. Absence of poly(ADP-ribose)polymerase-1 alters nuclear factor-kappa B activation and gene expression of apoptosis regulators after reperfusion injury. Mol. Med. 2003, 9, 143-153. [CrossRef] [PubMed]

72. Martignago, I.; Incorvaia, C.; Ridolo, E. Preventive actions of allergen immunotherapy: The facts and the effects in search of evidence. Clin. Mol. Allergy 2017, 15, 13. [CrossRef] [PubMed]

73. Seismann, H.; Blank, S.; Braren, I.; Greunke, K.; Cifuentes, L.; Grunwald, T.; Bredehorst, R.; Ollert, M.; Spillner, E. Dissecting cross-reactivity in hymenoptera venom allergy by circumvention of $\alpha-1,3$-core fucosylation. Mol. Immunol. 2010, 47, 799-808. [CrossRef] [PubMed]

74. Brehler, R.; Grundmann, S.; Stöcker, B. Cross-reacting carbohydrate determinants and hymenoptera venom allergy. Curr. Opin. Allergy Clin. Immunol. 2013, 13, 360-364. [CrossRef] [PubMed]

75. Baldacci, S.; Omenaas, E.; Oryszczyn, M.P. Allergy markers in respiratory epidemiology. Eur. Respir. J. 2001, 17, 773-790. [CrossRef] [PubMed]

76. Perez-Riverol, A.; Miehe, M.; Jabs, F.; Seismman, H.; Romani Fernandes, L.G.; de Lima Zollner, R.; Jakob, T.; Brochetto-Braga, M.R.; Spillner, E. Venoms of Neotropical wasps lack cross-reactive carbohydrate determinants enabling reliable protein-based specific IgE determination. J. Allergy Clin. Immunol. 2018, 141, 1917-1919. [CrossRef] [PubMed]

77. Blank, S.; Neu, C.; Hasche, D.; Bantleon, F.I.; Jakob, T.; Spillner, E. Polistes species venom is devoid of carbohydrate-based cross-reactivity and allows interference-free diagnostics. J. Allergy Clin. Immunol. 2013, 131, 1239-1242. [CrossRef] [PubMed]

78. Müller, U.R. Recombinant hymenoptera venom allergens. Allergy Eur. J. Allergy Clin. Immunol. 2002, 57, 570-576. [CrossRef]

79. Müller, U.R. Insect Venoms. In Anaphylaxis; Karger: Basel, Switzerland, 2010; pp. 141-156.

80. Moreno, M.; Giralt, E. Three valuable peptides from bee and wasp venoms for therapeutic and biotechnological use: Melittin, apamin and mastoparan. Toxins 2015, 7, 1126-1150. [CrossRef] [PubMed]

81. Lee, S.H.; Baek, J.H.; Yoon, K.A. Differential properties of venom peptides and proteins in solitary vs. social hunting wasps. Toxins 2016, 8, 32. [CrossRef] [PubMed]

82. Caruso, B.; Bonadonna, P.; Bovo, C.; Melloni, N.; Lombardo, C.; Senna, G.; Lippi, G. Wasp venom allergy screening with recombinant allergen testing. Diagnostic performance of rPol d 5 and rVes $\mathrm{v} 5$ for differentiating sensitization to Vespula and Polistes subspecies. Clin. Chim. Acta 2016, 453, 170-173. [CrossRef] [PubMed] 
83. Van Vaerenbergh, M.; Cardoen, D.; Formesyn, E.M.; Brunain, M.; Van Driessche, G.; Blank, S.; Spillner, E.; Verleyen, P.; Wenseleers, T.; Schoofs, L.; et al. Extending the honey bee venome with the antimicrobial peptide apidaecin and a protein resembling wasp antigen 5. Insect Mol. Biol. 2013, 22, 199-210. [CrossRef] [PubMed]

84. Müller, L.; Vogel, M.; Stadler, M.; Truffer, R.; Rohner, E.; Stadler, B.M. Sensitization to wasp venom does not induce autoantibodies leading to infertility. Mol. Immunol. 2008, 45, 3775-3785. [CrossRef] [PubMed]

85. Lu, G.; Villalba, M.; Coscia, M.R.; Hoffman, D.R.; King, T.P. Sequence analysis and antigenic cross-reactivity of a venom allergen, antigen 5, from hornets, wasps, and yellow jackets. J. Immunol. 1993, 150, 2823-2830. [PubMed]

86. Korošec, P.; Valenta, R.; Mittermann, I.; Čelesnik, N.; Šilar, M.; Zidarn, M.; Košnik, M. High sensitivity of CAP-FEIA rVes v 5 and rVes v 1 for diagnosis of Vespula venom allergy. J. Allergy Clin. Immunol. 2012, 129, 1406-1408. [CrossRef] [PubMed]

87. Vinzón, S.E.; Pirpignani, M.L.; Nowicki, C.; De Jimènez Bonino, M.B. Molecular cloning and expression in Pichia pastoris of a hypoallergenic antigen 5. Protein Expr. Purif. 2010, 73, 23-30. [CrossRef] [PubMed]

88. Eberlein, B.; Krischan, L.; Darsow, U.; Ollert, M.; Ring, J. Double positivity to bee and wasp venom: Improved diagnostic procedure by recombinant allergen-based IgE testing and basophil activation test including data about cross-reactive carbohydrate determinants. J. Allergy Clin. Immunol. 2012, 130, 155-161. [CrossRef] [PubMed]

89. Ribeiro, J.M.C.; Francischetti, I.M.B. Role of arthropod saliva in blood feeding: Sialome and post-sialome perspectives. Annu. Rev. Entomol. 2003, 48, 73-88. [CrossRef] [PubMed]

90. Valenzuela, J.G.; Pham, V.M.; Garfield, M.K.; Francischetti, I.M.B.; Ribeiro, J.M.C. Toward a description of the sialome of the adult female mosquito Aedes aegypti. Insect Biochem. Mol. Biol. 2002, 32, 1101-1122. [CrossRef]

91. Mans, B.J.; Andersen, J.F.; Francischetti, I.M.B.; Valenzuela, J.G.; Schwan, T.G.; Pham, V.M.; Garfield, M.K.; Hammer, C.H.; Ribeiro, J.M.C. Comparative sialomics between hard and soft ticks: Implications for the evolution of blood-feeding behavior. Insect Biochem. Mol. Biol. 2008, 38, 42-58. [CrossRef] [PubMed]

92. Ferry, X.; Eichwald, V.; Daeffler, L.; Landry, Y. Activation of subunits of Gi2 and Gi3 proteins by basic secretagogues induces exocytosis through Phospholipase $\mathrm{C}$ and arachidonate release through Phospholipase C in Mast Cells. J. Immunol. 2001, 167, 4805-4813. [CrossRef] [PubMed]

93. Kinet, J.P. The high-affinity IgE receptor (Fc epsilon RI): From physiology to pathology. Annu. Rev. Immunol. 1999, 17, 931-972. [CrossRef] [PubMed]

94. Nadler, M.J.; Matthews, S.A.; Turner, H.; Kinet, J.P. Signal transduction by the high-affinity immunoglobulin E receptor Fc epsilon RI: Coupling form to function. Adv. Immunol. 2000, 76, 325-355. [PubMed]

95. Koshikawa, N.; Nakamura, T.; Tsuchiya, N.; Isaji, M.; Yasumitsu, H.; Umeda, M.; Miyazaki, K. Purification and identification of a novel and four known serine proteinase inhibitors secreted by human glioblastoma cells. J. Biochem. 1996, 119, 334-339. [CrossRef] [PubMed]

96. Kischnick, S.; Weber, B.; Verdino, P.; Keller, W.; Sanders, E.A.; Anspach, F.B.; Fiebig, H.; Cromwell, O.; Suck, R. Bacterial fermentation of recombinant major wasp allergen Antigen 5 using oxygen limiting growth conditions improves yield and quality of inclusion bodies. Protein Expr. Purif. 2006, 47, 621-628. [CrossRef] [PubMed]

97. Bohle, B.; Zwolfer, B.; Fischer, G.F.; Seppala, U. ; Kinaciyan. T.; Bolwig, C.; Spangfort, M.D.; Ebner, C. Characterization of the human T cell response to antigen 5 from Vespula vulgaris (Ves v 5). Clin. Exp. Allergy 2005, 35, 367-373. [CrossRef] [PubMed]

98. Macchia, D.; Cortellini, G.; Mauro, M. Vespa crabro immunotherapy versus Vespula-venom immunotherapy in Vespa crabro allergy: A comparison study in field re-stings. World Allergy Organ. J. 2018, 11, 3. [CrossRef] [PubMed]

99. Vovolis, V.; Mikos, N.; Koutsostathis, N. Successful venom immunotherapy to paper wasp, in IgE-venom negative patient. Allergol. Immunopathol. 2011, 39, 57-58. [CrossRef] [PubMed]

100. Przybilla, B.; Ruëff, F. Hymenoptera venom allergy. J. Dtsch. Dermatol. Ges. 2010, 8, 114-127. [CrossRef] [PubMed]

101. Biló, B.M.; Rueff, F.; Mosbech, H.; Bonifazi, F.; Oude-Elberink, J.N.G. Diagnosis of Hymenoptera venom allergy. Allergy 2005, 60, 1339-1349. [CrossRef] [PubMed]

102. Jutel, M.; Akdis, M.; Blaser, K.; Akdis, C.A. Mechanisms of allergen specific immunotherapy-T-cell tolerance and more. Allergy 2006, 61, 796-807. [CrossRef] [PubMed] 
103. Linhart, B.; Valenta, R. Molecular design of allergy vaccines. Curr. Opin. Immunol. 2005, 17, 646-655. [CrossRef] [PubMed]

104. Bazon, M.L.; Perez-Riverol, A.; Dos Santos-Pinto, J.R.A.; Fernandes, L.G.R.; Lasa, A.M.; Justo-Jacomini, D.L.; Palma, M.S.; de Lima Zollner, R.; Brochetto-Braga, M.R. Heterologous expression, purification and immunoreactivity of the antigen 5 from Polybia paulista wasp venom. Toxins (Basel) 2017, 9, 259. [CrossRef] [PubMed] 